\title{
$\overline{\overline{\text { 解 }}}$ \\ 液 中 放 電 成 形 法
}

\section{1. まえがき}

液中放電成形法は最近注目されている高エネルギ速度 加工法の一つであり，爆発成形法の持っている種々の利 点, すなわち,

(1) 大形のプレス機械を設置しなくても大形部品の成 形が可能であり，また雌型のみで雄型は不用であること， したがって少量多機種生産にも適すること

（2）従来の静的な成形法では成形困難であった高強 度, 高温高強度の材料の中にも高ひずみ速度成形では变 形能の増大するもののあること

(3) スプリングバック量が少なく製品精度の向上が期 待できること

などを生かし，かつエネルギ制御や取扱いを簡単にする ために，爆薬のかわりにコンデンサに貯えられた電気エ ネルギを用いようとするものである。

液中放電によって圧力が発生することは古くから知ら れていた1が，これによって金属の成形を行なうことが 試みられたのはごく最近のことである。アメリカにおい ては特に盛えであり, 数十社において研究が進められて いるといわれ，実用機も数種発表されている。

わが国においてもアメリカの発表2)334) とほとえぞ同時 飞各方面で研究が行なわれてきており，基礎的資料む徐 徐に整いつつある現状である。

本文ではこれまで行なわれてきた諸研究を概観し, 最 近の成果にもふれてみたい。

\section{2. 原理}

図 1 に示すような回路によってコンデンサを高電圧に 充電し，所定のエネルギに達したならばスイッチを閉じ て液中に設けられた間隙において放電させる。この液中 放電によって高圧力が発生し, 液体を介して衝撃波が被 加工物に伝達され，成形を行なう。

\section{1 放電回路}

回路の特性が成形に及ぼす影響については藤村 ${ }^{5}$ によ

* 正会員 機械試験所
って詳しく報告されており，本誌に㧅いても述べられる ものと思うので，ここでは基本的な事項についてごく簡 単に触れるにとどめる。

放電回路は等価的に，抵抗，インダクタンス，静電容 量の直列回路とみなすことができる。いまコンデンサが 電圧 $V$ に充電されているときスイッチを閉じて放電する 場合, 回路に流れる電流について考察してみると次式が 成立する。

$$
\begin{aligned}
R i+L \frac{d i}{d t}=\frac{1}{C}-\int i d t \\
\text { ここに } \quad R: \text { 回路抵抗 } \\
L: \text { 回路インダクタンス } \\
C: \text { 静電容量 } \\
i: \text { 電流 } \\
t: \text { 時間 }
\end{aligned}
$$

$R, L$ は厳密には時間の関数と考元られるが近似的に 一定とし, また衝撃大電流発生回路に抢いて一般に成立 する条件， $R^{2}<4 L / C$ の下に初期条件を考虑して上式を 解くと

$$
\begin{aligned}
& i=\frac{V}{\beta L}-e^{-\alpha t} \sin \beta t \\
& \text { ここに } \quad \alpha=R /(2 L), \quad \beta=\sqrt{1 /(L C)-R^{2} /\left(4 L^{2}\right)}
\end{aligned}
$$

この電流は減衰振動電流で, その最大值 $i_{m}$ および最 大值になる時間 $t_{m}$ はそれぞれ次式で与えられる。

$$
i_{m}=\frac{V}{\sqrt{\frac{L}{C}}} e^{-\frac{\alpha}{\beta} \tan ^{-1} \frac{\beta}{\alpha}}
$$

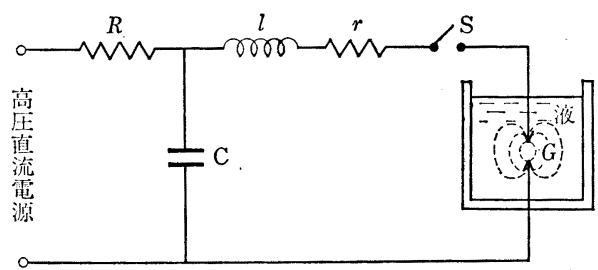

$R:$ 充電抵抗, $\mathrm{C}:$ コンデソサ群

$l:$ 回路インダクタンス, $r:$ 回路抵抗

$\mathrm{S}$ : 始動スイッチ, $G$ : 放電間隙

図 1 液中放電成形法の回路 


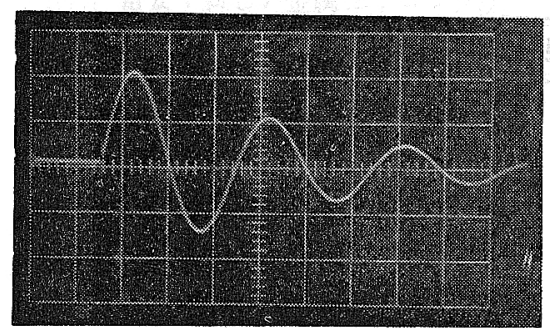

充電電压 : $10 \mathrm{kV}$, コンデンサ容量 : $200 \mu \mathrm{F}$ 電極間隙 : $3 \mathrm{~mm}$, 垂直軸 : $10 \mathrm{~V} / \mathrm{div}$

掃引速度 : $50 \mu \mathrm{s} / \mathrm{div}$, 分流器抵抗（值流にて） : $0.0009945 \Omega$

図 2 水中放電電流波形

$$
t_{m}=\frac{1}{\beta} \cdot \tan ^{-1} \frac{\beta}{\alpha}
$$

特に $R^{2} \ll 4 L / C$ のき汇

$$
\begin{aligned}
& i_{m} \doteqdot \frac{V}{\sqrt{\frac{L}{C}}} \\
& t_{m} \doteqdot \pi \sqrt{L C}
\end{aligned}
$$

である。円板形分流器によって得られた電流のオシログ ラム定 2 にあげる。このオシログラムの波形は電流が 減衰振動電流であることを示している。

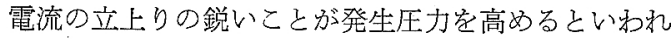
ており6)，このため怆回路のインダクタンスを極力小 さくして和かなくてはならない。

\section{2 放電エネルギ}

容量 $C$ のコンデンサが電圧 $V$ に充電されるときコンデ ンサに貯えられるェネルギWは

$$
W=\frac{1}{2} C V^{2}
$$

である。このエネルギを変えることによって金属の变形 量を制御するととができる。このため忙電圧または土 ンデンサ容量を変光ればよい事沙である。

コンデンサに貯えられたエネルギのうち，一部は回路 中において熱損失となり，残りは放電間隙に打いて放出 されると考光られるが，このエネルギも熱損失，音，光 のエネルギなどとしてかなり失われ，圧力発生の有効な エネルギは充電エネルギの数パーセントから 20〜30 パ 一七ントくらいであると言われている788。発生した圧 力の利用効率も考慮すると最終的な効辩はさらに低くな るものと考光られる。

\section{3 圧力波の特性}

\subsection{1 压力波の発生機構}

液中放電による高圧力発生の機構はいまだ詳しくはわ
かっていないが，大体次に述べるようなものと考觉られ ている ${ }^{91010}$ 。

液体中に置かれた電極間隙で衝撃大電流の放電を行な うと, 電極材料蛙よび放電点付近の液体は急激な温度上 昇堂生じ，てれによって発生した気体恃急激に膨張す る。しかしながらこの気体の膨張は周围の液体の慣性に より姷げられるため，気体は非常な高圧力之なり，周囲 の液体を厌縮して衝撃波を生ぜしめる。この衝撃波は液

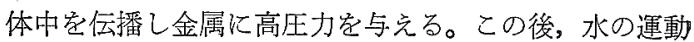
による圧力も加わるが成形への寄与について性詳しくる かってはいない。

\subsection{2 压力波の伝播と指向性}

放電間隙があまり大きくない場合には，発生気体は球 形となって膨張，収縮する ${ }^{10)}$ 加ら，て秃によって発生す る圧力波も球面波近いものと考えられる。球面弾性波 认関して次式分成立する。

$$
\begin{aligned}
& \frac{\partial u_{r}}{\partial t}=-\frac{1}{\rho_{0}} \frac{\partial P}{\partial r} \\
& \frac{1}{c_{0}{ }^{2}} \frac{\partial P}{\partial t}=-\rho_{0} \frac{1}{r^{2}} \frac{\partial}{\partial r}\left(r^{2} u_{r}\right)
\end{aligned}
$$

ここに, $u_{r}:$ 粒子速度の半径方向成分

$$
\begin{aligned}
P & : \text { 距離 } r \text { の点における压力 } \\
r & : \text { 原点汃らの距離 } \\
\rho_{0} & : \text { 密度 } \\
t & : \text { 時間 } \\
\epsilon_{0} & : \text { 音速 }
\end{aligned}
$$

式(9)安時間について微分し，式(8)安用いて稙子速度を 消去すると，

$$
\frac{1}{r^{2}}-\frac{\partial}{\partial r}\left(r^{2} \frac{\partial P}{\partial r}\right)=\frac{1}{c_{0}^{2}} \frac{\partial^{2} P}{\partial t^{2}}
$$

これは球面圧力波の波動方程式であり，この解は中心 汃ら外方晌ら波について，

$$
P\left(r_{1} t\right)-P_{0}=\frac{1}{r} f\left(t-\frac{r}{c_{0}}\right)
$$

上式において $P_{0}$ は擾乱のない場合の压力である。こ の結果から，このような波は一定速度 $c_{0}$ で伝播し，压 力の大きさ梳距離仅反比例するととがわかる。

衝撃波の伝播速度は音速よりも速く, 減衰と共に音速 に近づく。压力の減衰も音波の場合よりも速い。

プラグ形の電極を用いた成形に抢いては，放電電極の 院になる部分は成形量が少なくなると台報告されてお

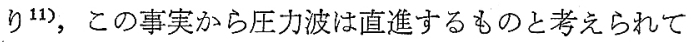
当。

また圧力波は電極の軸に対して直角な方向に強く出る 


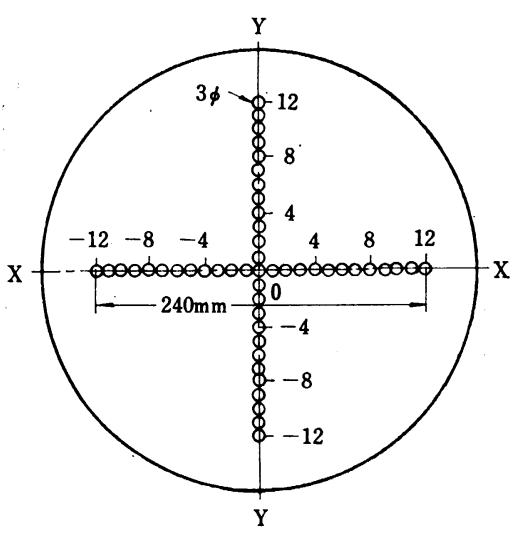

黄銅板 $0.2 \mathrm{~mm}$ 厚

図 3 圧力分布測定用の型

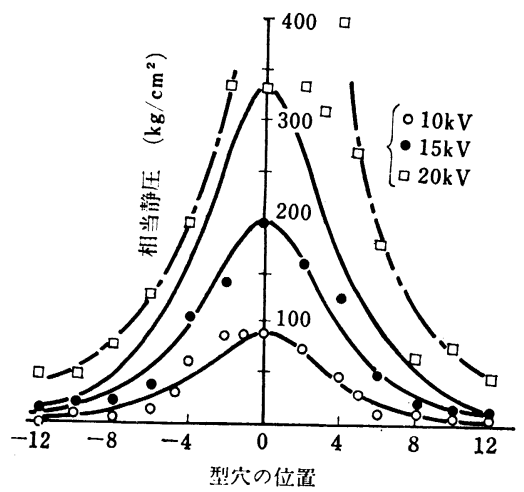

図4 相当静圧の理諭分布と測定相当 静圧 (奥島ほか)

とも言われている(12)が, 後述の単極式によっても成形で きることから軸方向にもかなりの圧力が発生するものと 考えられる。しかしながら, 圧力の空間分布の詳しい測 定はなく詳細は不明である。

\subsection{3 圧力分布}

成形においては, 試料にかかる圧力の分布を知ること は重要である。奥島他 ${ }^{18)}$ は図 3 に示すような，小穴のた くさんあいた型上に黄銅板をのせて放電により変形を行 ない, 静圧による変形量と比較して相当静圧を求めてい る。

この結果を図 4 に示す。試料平面上の圧力分布が等圧 面を放電電極の中心点を中心とする球面波によるものと して求めた理論計算と良く一致している。

\section{3. 液中放電成形法の方式の分類}

液中放電成形法は, 電極部の様式, 放電回路の形, 成 形品の種類, コンデンサ容量と充電電圧の取り方などに

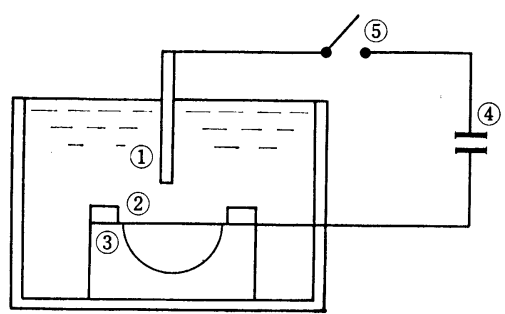

(1)電極 (2)素材板（電極をかねる） (3)型 (4) コンデンサ (5)スイッチ

図 5 単極式電極

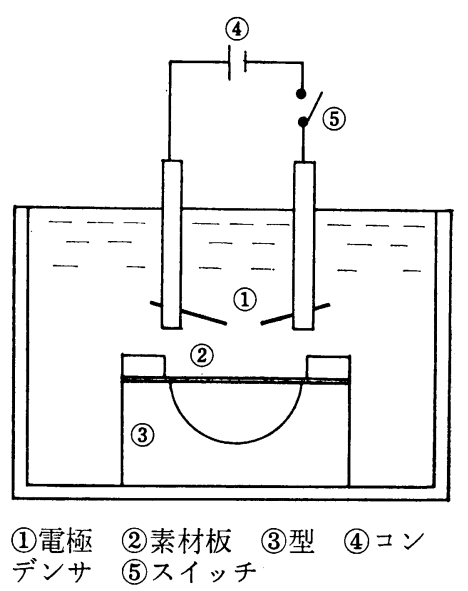

図 6 二極式電極

より種々の方法が考えられる。

\section{1 電極部の様式による分類}

\section{1 .1 単極式 ${ }^{14)}$}

これは図 5 に示すように被加工物を片方の電極とし， これに対向して他の電極を置きこの間で放電を行なうも のである。被加工物電極と対向電極との間に細い金属線 を張って後に述べる導線放電の形をとることもできる。

従来, 圧力の発生方向は放電溝の軸に直角な方向であ ると考えられていたが，軸方向にも十分な圧力が発生す るものであれば電極機構を簡略化することができるので 望ましいことである。この点から単極式の特性がはっき りするとおもしろいと思われる。ただ単極式では被加工 物を電極とするため, 被加工物に放電による傷ができる 欠点を持っている。

\section{1 .2 二極式}

図 6 に示すように二本の電極を対向させて設け，これ に対して被加工物を置く方法であり，最も原理的なもの である。放電条件（電圧, コンデンサ容量, 回路方式, 電極の形状, 液の種類) などによって最適の電極間隙が ありこれはあまり長くはない。したがってこの方式で 


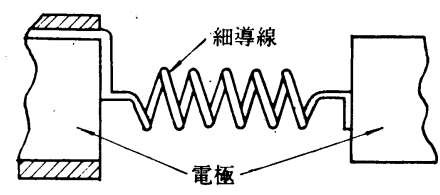

図 7 導線放電法

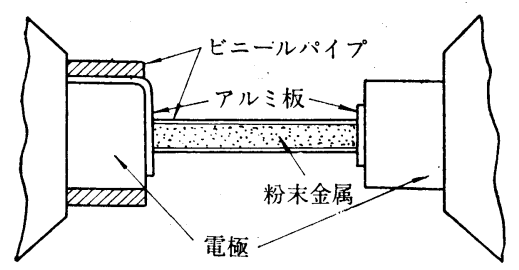

図 8 粉末金属放電法 (奥島ほか)

は圧力源としては点源に近いものとなり加工品の形状に よっては有効に圧力が利用されない場合もある。また放 電により電極は消耗するのでこれを正すように調整しな ければならない。

\section{1 .3 導線放電}

これは図 7 に示すように電極間に細い金属線を張り， 衝撃大電流によりこの金属線を気化させて圧力を発生さ せるものである。導線放電を用いることにより電極間隙 を広げて圧力源を線状にすることができ，また放電を安 定に発生させることができる。圧力源が拡大することに よりエネルギを有効に使用できる利点があり, 実際の成 形には多くこの方式が用いられる。特にパイプのバルジ 加工などにおいては有効である。

欠点としては金属線を一回の放電ごとに取り換えねば ならないことがあげられる。

\section{1 .4 金属粉末放電}

この方法は最近奥島他 ${ }^{15}$ )が発表したもので，図８亿 示すごとく上述の導線に代えてビニールパイプに金属 粉末を圧入したものを電極間に挿入して放電するもの で，この方法により出力が向上することが報告されてい る。

\section{2 放電回路の形式による分類}

これには図 9 に示すような各種のものが考えられる。 図示の方式(1)はスイッチSは開放としておき，放電間隙 $G$ は放電条件による適切な間隔に調整しておく。充電電 圧が所定の值に達したときスイッチを閉じて放電間隙で 放電させるものである。

方式(2)ではスイッチとして気中補助間隙を用い放電さ せようとする電圧に適合した間隙に調整しておき，充電

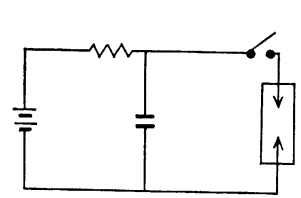

(1)

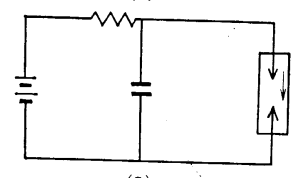

(3)

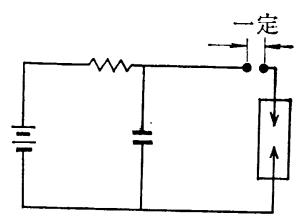

(2)

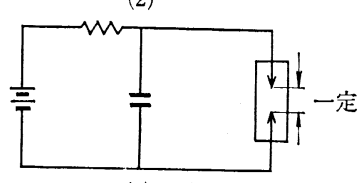

(4)
図 9 放電回路の形式

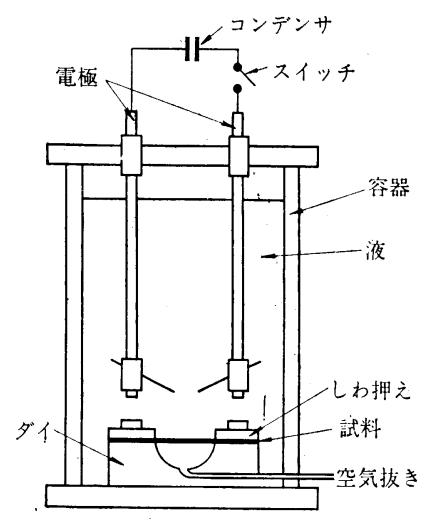

図10 液中放電成形法による板金成形

を行なうと，あらかじめ規定した間隙に適合した電圧に 達したとき放電が行なわれる。

方式(3)は放電開始用のスイッチは持たず，放電間隙は 十分拡げておく。充電を行なって所定の電圧に達したと き放電間隙を縮めて行き, 電圧に適合した間隙で放電を 起こさせるものである。

方式(4)は方式(3) と同様汇放電開始用スイッチは持た ず，放電間隙を放電させようとする電圧に適した間隔に 調整しておく。充電を行ない電圧が間隙に適合した值に 達したとき放電が行なわれる。

これら諸方式の長所短所をあげると，方式(1)および(2) は液体が導電性のものでも良く, また導線放電も可能で あるが，スイッチにおける損失がある。方式(3)と(4)はス イッチにおける損失はないが絶縁性の液体においてしか 使用できない。方式(1),(2),(4)においては間隙の調整が面 倒である。

\section{3 成形品による分類}

\subsection{1 板金成形}

これは図10に示すように板金のプレス成形を行なうも 


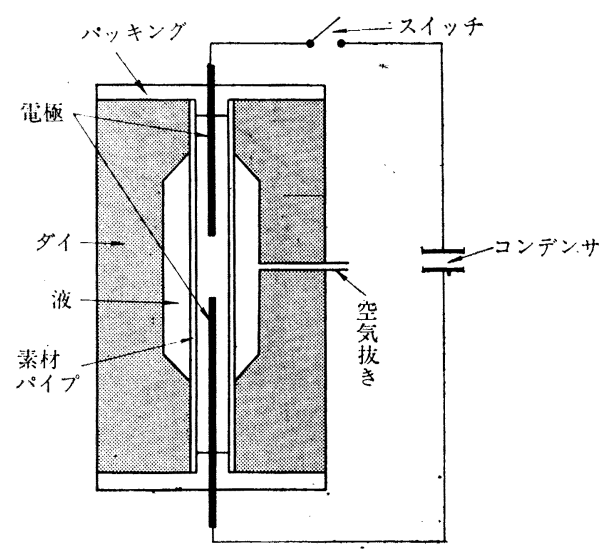

図11 液中放電によるパイプの成形

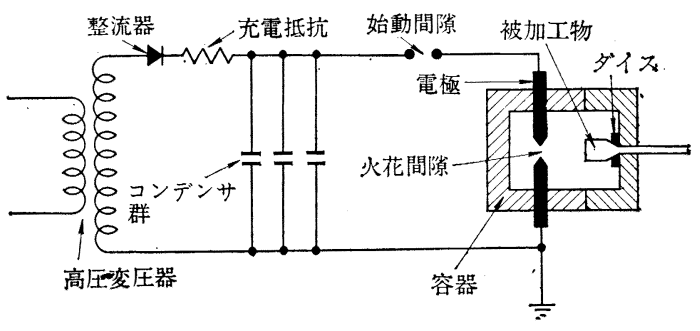

図12 液中放電圧押出法

のであり, 放電点に対向して試料, 型をおいて成形を行 なうものである。

3.3.2 パイプのバルジ加工

これは図11に示すようにパイプ内に液体を満たし，こ こに放電点を設けパイプの外側に型をおいてパイプのバ ルジ加工を行なうものであり, 液中放電成形法の実用化 という点から考えると最も有望な成形法である。

\subsection{3 押出し加工}

図12に示すように容器中にダイスを取付け, 素材を設 置し放電圧により押出す方法 ${ }^{16)}$ で, 潤滑状態の改善, 液 圧によるダイスの補強に効果があると考えられている。

\section{4 充電電圧とコンデンサ容量から見た方式の相違}

同一充電エネルギを得ようとする場合, コンデンサ容 量を大きくして電圧を比較的低くする方法と, 逆に充電 電圧を高くしてコンデンサ容量を小さくする方法とが可 能であり，実際にも両者が行なわれている。

強い衝撃波を得るには電流の立上りが鋭い方が有効で あるといわれているがこの観点からすれば高電圧小容量 方式の方が望ましいことになる。一方，金属成形には衝 撃波よりむしろ静的な圧力の方が望ましいとする考え方 もあり，この観点からは大容量低電圧方式がとられるこ
とになる。

もちろん, 充電電圧, ヨンデンサ容量の決定には上に 述べたこと以外にも技術的, 経済的問題が種々あるため ぞちらが有利かを一概に決めることはできない。

\section{4. 液中放電成形機の構成}

前掲の図 1 に示すように液中放電成形機は衝撃大電流 を発生させるための電気的部分と, 放電によって発生し た衝撃圧力を種々の成形加工に利用する成形部分から成 っている。

\section{1 電気部分}

電極間に火花放電を結ばせ衝撃大電流を通じるには, 瞬間的にかなり大きいエネルギを必要とする。このエネ ルギを得るためには普通コンデンサを高電圧に充電して 静電エネルギを貯える方法をとる。このような方法にお ける電気部分の構成はコンデンサ群, 高圧変圧器, 整流 器, 電圧調整器, 放電始動スイッチなどからなる。

\section{2 成形部分}

成形部分は分類の項で述べたように，圧力の利用の仕 方により種々の形のものを考えることができる。このよ うな種々の装置によってしぼり加工, バルジ加工, ライ ニング，スエージング，穴あけ加工などの諸加工および これらを組合わせた成形加工を行なうことができる。

このような成形部は基本的な構成要素として液容器, 型，乙わ押え，空気抜きなどを持っている。空気抜きは 型と被加工物との間の空気を排出して完全な成形を行な うために設けるものである。

実用機においては, 型, 被加工物の出し入れなどを考 慮した使いやすい構造が重要となる。

\section{5. 成形に影響する種々の要素}

\section{1 充電電圧とコンデンサ容量}

前述のように，コンデンサに貯えられるエネルギは1/2 $C V^{2}$ であるから，電圧またはコンデンサ容量を変えて充 電エネルギを変化し発生圧力を制御することができる。 コンデンサを増すと必然的に装置が大きくなるからあま り大きくすることはできない。また容量を連続的に変化 することは困難である。したがってエネルギの制御はお もに電圧を変えて行なわれる。電圧によれば広い範囲に わたって連続的な制御が可能である。しかしながら電圧 が高くなるにつれ回路の絶縁が困難になってくる。

しぼりおよび張出し成形時の变形量に及ぼす電圧およ びュンデンサ容量の影響については二, 三の研究 ${ }^{17) 18) 19) ~}$ が見受けられる。これらの結果を図13に示す。縦軸はブ ランク中央部の变形高さである。図14に筆者の行なった 


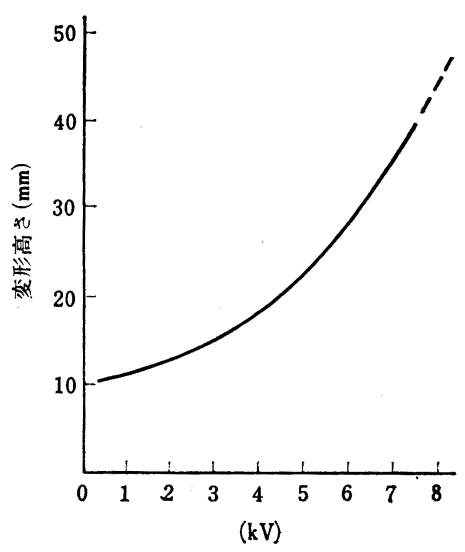

(a) (熊沢ら)

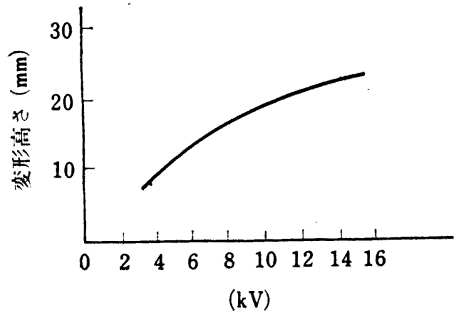

(b)（向坂）

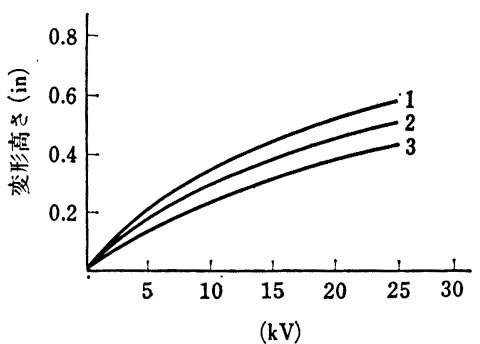

(1) $: 10.5 \mu \mathrm{F}$, (2) $: 7.5 \mu \mathrm{F}$, (3) $: 4.5 \mu \mathrm{F}$ (c) (Kegg)

図13 充電電压と中央部の変形高さ

実験結果の一部を示す。これらの結果に一定の傾向が見 受けられないのは, 圧力源の形状, 容器の形状等による 圧力の伝播状態, 回路条件, 被加工物の材質その他が影 響するためであると考えられる。

同一エネルギであっても電圧と容量の組合わせ方によ って成形効果は異なるといわれているが，この違いはあ まり大きくはないようである。

一般に充電エネルギ $W$ と変形高さ $h$ との関係は, 他の 条件を一定とした場合

$$
h=K W^{a}
$$

$K, a$ は定数

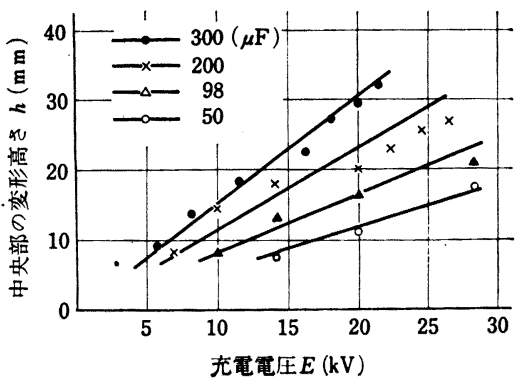

(a)

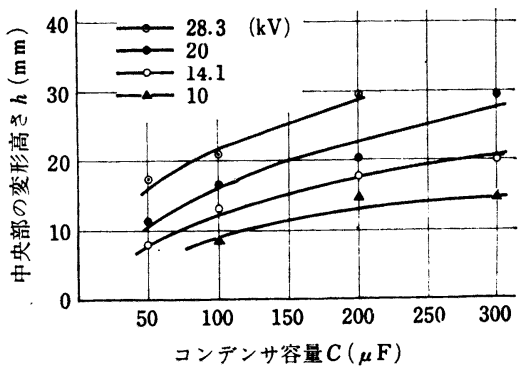

(b)

図14 充電電圧およびュンデンサ容量と中 央部の变形高さ

なる形で表わされるとされており， R. L. Kegg は定数 $a$ として0.36を, Duncan7) 0.52〜0.56を与えている。 筆者の実験結果からはこの定数として 0.45 が得られた。

\section{2 媒体夜の種類}

媒体液の影響について理論的な説明を与えることは放 電圧力の発生機構の明らかでない現在では困難である。 実験的には变圧器用絶縁油において高い玨力が発生する ことが知られている。液体の熱的, 電気的, 力学的な諸 特性が複雑な影響を持つものであろう。図15に井上他に よる実験結果をあげておく。これは図16に示すような砲 形の装置により放電圧で弾を打ち出し, この弾の飛行距 離から液体の効果を検討したものである。

なお油類は放電によりスラッジを生じ取扱いにくい欠 点を持っているため, 一般には水道水が使われている。

\section{3 電極材料とその形状}

電極材料, 電極形状は, 発生圧力の大きいこと, 放電 が安定に行なわれること, 消耗量の少ないことなどを満 足するものでなければならない。材料としてはアルミニ ウム，黄銅などが発生圧力が大きいと言われているが, これらでは消耗量も多くなる。電極形状は放電の安定性 からは平面電極が良いということであるが，発生圧力は 先端のとがった電極の方が大きい。 


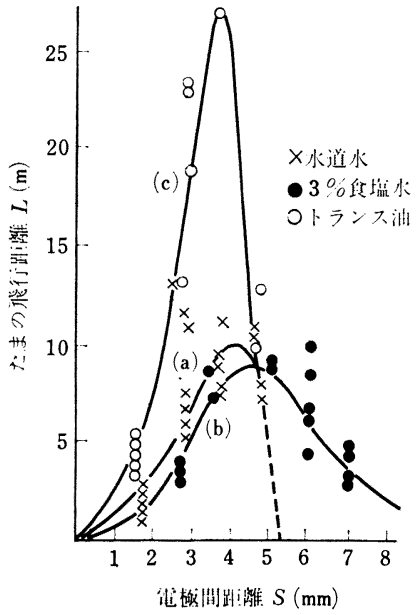

図15 液体の種類と出力（井上ほか）

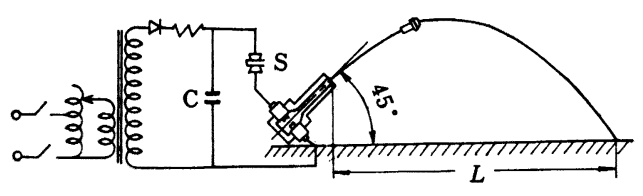

$\mathrm{C}:$ コンデンサ $\mathrm{S} ：$ スイッチ $L$ ：たま飛行距離

図16 弾丸発射装置（井上ほか)

導線放電を行なう場合には, 放電は安定になり電極の 材質, 形状については考虑しなくてよいが, 放電導線の 材質，太さ，長さなどが問題となってくる ${ }^{20) 。 ~}$

\section{4 放奄間隐}

単極式および二極式の放電方式においては電極間の間 隙は成形効果, 放電の安定性のうえから重要である。

液の種類, 放電回路が定まると, ある電圧において放 電可能な最大間隙があり，これより間隙を広げた場合は もはや放電しなくなる。一般的に言って電極間隙が広い 方が成形に有利になるが，上の条件で制限されるわけで ある。わずかの間隙の違いも成形効果に影響して成形品 にばらつきを与える結果となりやすい。

したがって，導線放電によって放電を安定させること はこの点からも有効である。また絶縁性の液中において はじめに間隙を十分広げておき, 充電終了後徐々に縮め て行って放電を起こさせる方式は, 放電可能な最大間隙 付近で放電するものと考えられるから有効であろう。

\section{5 放電点と被加工物との距離}

衝撃波の減衰は急速であるから, 放電点と被加工物と の距離が近いほど利用できる圧力は一段と大きくなる。 前述の Kegg ${ }^{17)}$ によると板の張出し高さは，この距離の 0.88 乗に逆比例するという実験結果が示されている。た
だあまりにこの距離が近くなると，放電点付近の熱の 影響や，放電が被加工物との間で起こることも考えられ るので注意せねばならない。

な少衝撃波は距離と共に減衰するばかりでなく形も鋭 さを失ってくるから，成形に及ぼす影響も異なってくる と考えられる。

\section{6 型}

放電成形法においては変形速度が非常に速いから, 型 と被加工物との間の空気の排除が問題となる。空気の排 除が完全でない場合には成形は不完全となり，また焼付 きを起こす場合もあると言われる。空気抜きのために型 に穴を開けたり，型を間隙を設けて取り付けたりするこ とが行なわれる。空気抜き穴の数, 大きさなどは型の強 度と成形品への悪影響のない範囲で決められねばならな いがこの点に関する資料はない。

空気抜きに真空ポンプを用いることは，シールの問題 や経済的な難点はあるが有効な方法である。

\section{7 しわ押え, 潤滑}

放電成形法による板金のしぼり加工においても普通の しぼり加工におけると同様に，しわ押え装置が必要であ る。しわ押えの方式，しわ押え力などが成形に及ぼす影 響についてはいまだ詳しい研究はなされていない。

潤滑もまた高速变形過程においては，一般の成形にお けると同様またはそれ以上に重要であると考えられる が，これも詳しい研究はなく今後の課題である。

\section{6. 高エネルギ速度成形における塑性変形}

液中放電成形法においては変形は高速で行なわれるの で，金属の高速変形時の特性が重要となる。

この問題に関しては, 専門分野の諸氏が本誌に執筆さ れるはずであるので，本文ではきわめて概略の研究展望 を記すにとどめる。

\section{1 高速引張りにおける伸びとバルジ加工および 張出加工における成形性}

Kármán ${ }^{21)}$ の理論の検証として，また高速変形におけ る金属の諸性質を調べるため，高速引張り試験が行なわ れているが，試験法が確立されていないためか統一的な 結果は得られていないようである。ここでは，二，三の 報告を参照してその概略をみることにする。

河田 ${ }^{22)}$ は爆薬を用いた試験機により引張り速度 120 $\mathrm{m} / \mathrm{s}$ までの範囲で実験を行ない，次のような結果を得 ている。

材料としては耐熱性および慣用の実用材料を選びまた 結晶形により面心立方, 体心立方, および稠密六方格子 にわたるように選えでいる。伸び対引張り速度の関係は 
次の三つのグループに分かれた。

(a) 動的伸びが静的伸びより増大しているグループ： アルミニウム, ジュラルミン

(b) 伸びがほとんど引張り速度により変わらないもの : 18-8 ステンレス鋼

(c) 伸びが速度とともに減少するグループ: 軟鋼, チ タニウム

ここで(a)および(b)グループの材料は面心立方格子であ り, (c)グループの軟鋼は体心立方, チタニウムは稠密六 方格子である。

また，作井 ${ }^{23}$ )他は回転円板式高速衝撃引張り試験機に

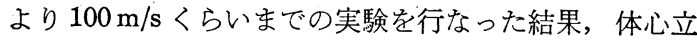
方晶金属では伸びは静的試験から動的になるにしたがっ て多少低下するが $40 \mathrm{~m} / \mathrm{s}$ ではかえって増大する，面心立 方金属は変形速度の変化に対して伸びはほとんど変化し ない，六方晶金属では伸びは静的試験にくらべて著しく 小となることなどを報告している。

W. W. Wood ${ }^{24)}$ は引張り試験, パイプのバルジ加工, 板の張出し成形における成形性を速度と温度を種々変え て調べている。図17にその中から常温における成形性の 速度依存を示す図をあげておく。とくに 17-7-PH ステ ンレス鋼は, ある速度域で成形性の増大することを示し ている。

板の張出し加工やパイプのバルジ加工においては，金 属の物性以外に慣性作用が材料のくびれによる破損を妨 げ，成形性を向上するという効果をもたらすことも考㝋 ねばならない。

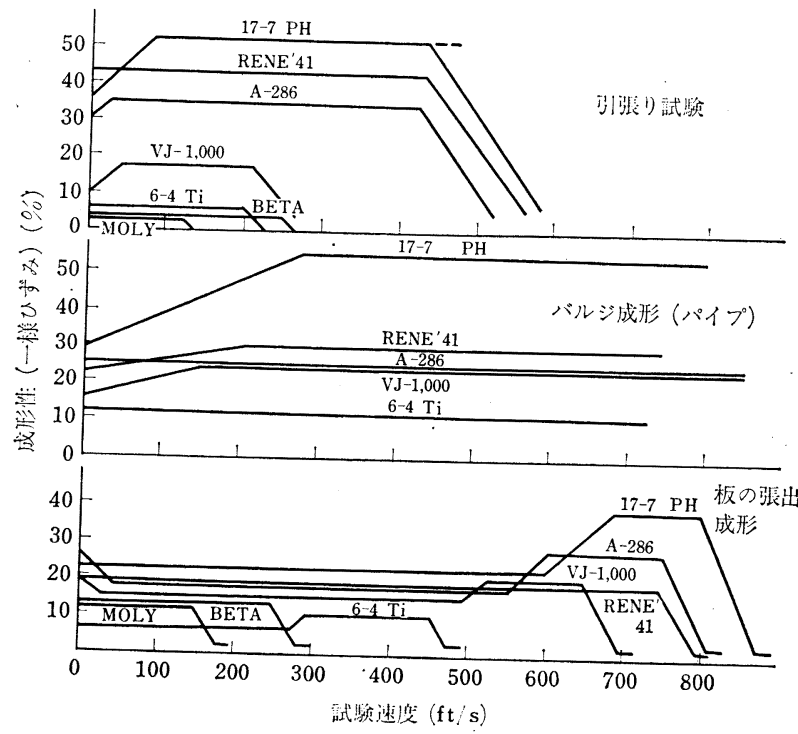

図17 成形性の速度依存 (W.W.Wood)

\section{2 金属の動的变形の解析}

衝撃圧を受けた金属板は, ある速度を得て動き出し 塑性変形する。このような金属板の動的変形の解析 は Hudson ${ }^{25)}$ により行なわれている。

Hudson は周辺の固定された薄い金属円板について。 はじめに板に垂直な一様な速度が与えられたとき，固定

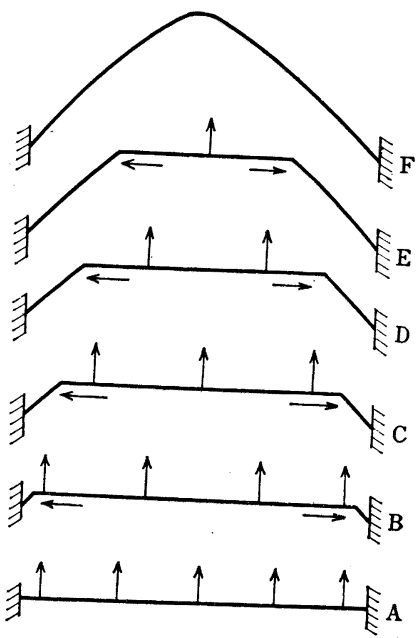

図18 薄板の変形過程 (Hudson)
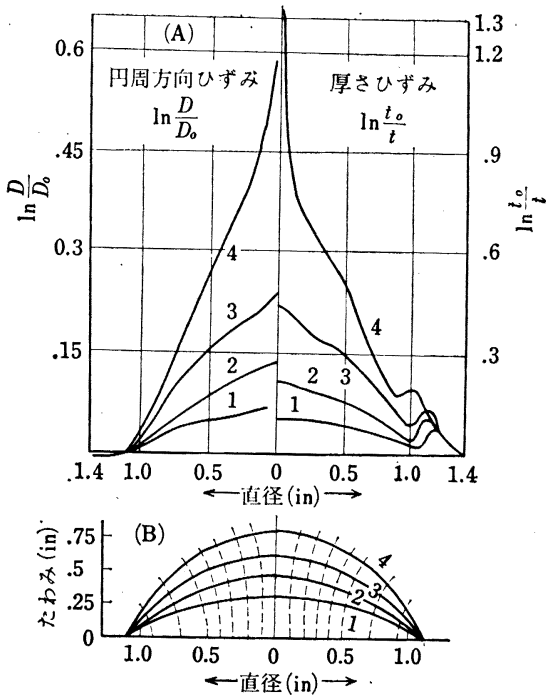

試料 : 16 s.w.g. アルミニウム 放電エネルギ：

(1) $520 \mathrm{ft} \cdot 1 \mathrm{lbs}$, (2) $930 \mathrm{ft} \cdot \mathrm{lbs}$, (3) $1550 \mathrm{ft} \cdot \mathrm{lbs}$,

(4) $2430 \mathrm{ft} \cdot \mathrm{lbs}$.

(A) ひずみ分布

(B)成形後の形状 
された周辺から曲げの波が中央部に向って伝播してゆく と考えて力学的解析定行なっている。図18亿この变形過 程を示す概念図をあげる。

\section{3 液中放電成形法の場合}

Duncan $^{7}$ や奥島他 ${ }^{15)}$ によると放電成形による板金の 張出し加工の場合には静圧の場合ほ核球状に近く变形す るのに対し，試片中央部が薄くなり円主い形に成形され るとのことである。このような変形の仕方は懪登成形の 場合にも見られるもの吕であり，变形が高速で行なわれ る場合の特徵であるる思わ秃る。図19にDuncan の実 験によるひずみ分布および成形形状定示す。

\section{7. 放電成形機と成形品の例}

\section{1 液中放電成形機の例}

放電成形機の1例として機械試験所で試作した板金成 形用の装置について説明する。

図20注成形部の概観写真である。表 1 亿本機の仕様安 あげる。成形部の主要部ならびに電気回路の構成を示す 亲統図を図21に示す。以下に各部について説明する。

\section{1 .1 成形部}

成形部は 4本の支柱に容器部多涸定されており，放電 はこの容器内で行なわ和る。容器の下方には型を取付け たテーブルがあり，試料は型の上に置かれる。試料が型 上に設定された後, テープルは上昇して容器の下部に押 し付けら机て固定される。固定されると同時にしわ捝 が動作する。これらの動作はすべて油圧歌動により自動 的に行なっている。この操作が終わると容器内に液が注 入される。一方止力家調整する一つの手段として電極閒 陌および被加工物と電極間の距離が調整される。また場 合によっては真空ポンプによって試料と型の間の空気排 出它行なら。これで準備動作は完了する。

\section{表 1 試作液中放電成形機仕椂}

\begin{tabular}{|c|c|}
\hline 最大充電エネルギ & $135 \mathrm{~kJ}$ \\
\hline 最高 充電電圧 & $30 \mathrm{kV}$ \\
\hline 最大コンデンサ容量 & $300 \mu \mathrm{F}$ \\
\hline 放電回路インダリタンス & $5 \mu \mathrm{H}$ 以下 \\
\hline 放電回路抵抗 & $0.02 \Omega$ 以下 \\
\hline 充 電 所 要 時間 & $20 \sim 60 \mathrm{~s}$ \\
\hline 源 & $50 \mathrm{c} / \mathrm{s}, 200 \mathrm{~V}$ \\
\hline 成形サイクル & $4 \mathrm{~min}$ 以下 \\
\hline 放電点と試料間距催調整範罒 & $0 \sim 350 \mathrm{~mm}$ \\
\hline 電極間隙調整範囲 & $0 \sim 100 \mathrm{~mm}$ \\
\hline 成形品最大寸法 (ブランク直径) & $300 \mathrm{~mm}$ \\
\hline 乙わ押え力調整範囲 & $0 \sim 52.7 \mathrm{t}$ \\
\hline 容 器 容 積 & $92 l$ \\
\hline
\end{tabular}

容器部としては常に液を満たしておき，液漏れ学防く たるに下面にゴム膜などを設ける方法，図22に示するう に容器部定下にして上方に型を学柇式などが考光られ る。図22の方法は実用上かららは液を常時满たしておくこ をができるとと，成形品の取出しが容易なととなどの点 ですぐ䟕ていると思われる。

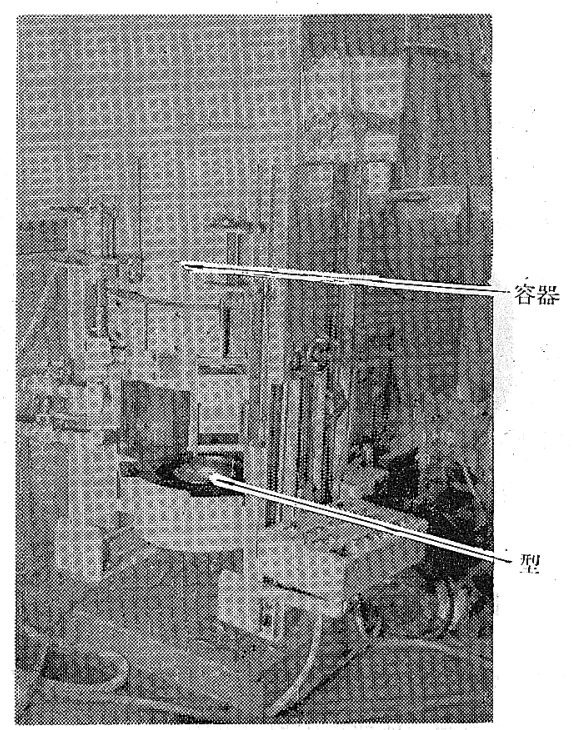

図20 液中放電成形機概観

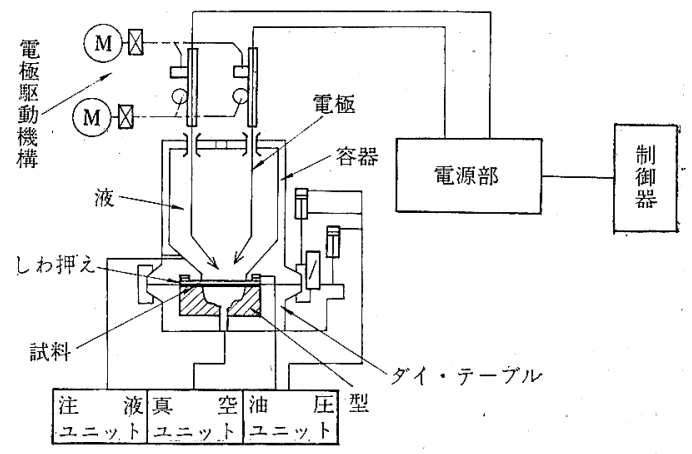

図21 系統図

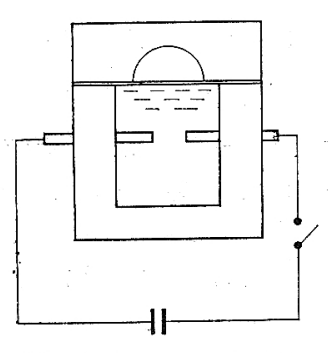

図22 型空上に打く成形法 


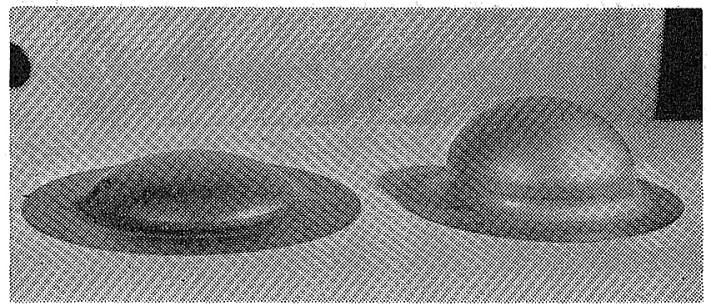

(a) 絞り成形

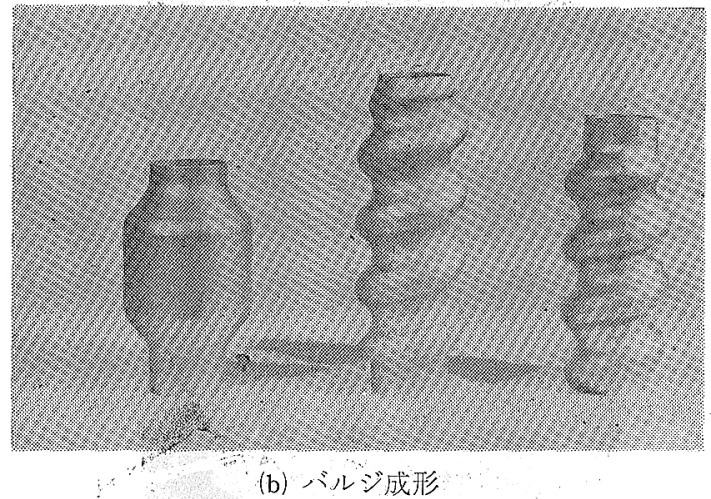

図23 液中放電成形法による成形例

\section{1 .2 電源部}

電源部は上記の成形部の㸡電間隙へエネルギを供給す る部分で，コンデンサ充電用の高圧トランス, 整流器, コンデンサ群，始動用球間隙スイッチ，低压イオンスイ ッチおよびトリガ回路, 残留電荷除去機構なぞで構成さ れている。放電回路のインダタタンスをできるだけ小さ くするために，導体として同軸ケーブルを用いている。 始動スイッチは效率に影響する重要な部分である。低圧 イオンスイッチは放電時に騷音を発しないこと, 損失の 少ないとと,インダクタンスの小さいこと，始動が迅速 であることなどの長所を持つが，電流容量，寿命などの 点に問題が残されている。

\section{2 成形品例}

図23に成形品の例崖あげる。(a)は板金の自由成形品， (b)はパイプのバルジ加工例である。

\section{8.むす び}

放電成形用電気回路，電流波形の成形に及济す影響， 高ひずみ速度における金属材料の挙動などについてはそ れぞれ專門分野の諸氏が本誌で詳細な解説定されること になっているので本文では液中放電成形法の概要を皮相 的に説明したのにとどめた。この点は大方のご了承を願 いたい。

ともあれ，液中放電成形法は新しい加工法であるため
今後の系統立った研究が必要であるが，この方法は現時 点においても種々の優狄た特幑を持つものであると考え られるから，研究成果の蓄積と適切な適用分野の出現に より飛躍的に発展する可能性穴持つ加工法であるという ことができよう。

また液中放電は単に成形のタに適用されるばかりでな く, 固体の粉确, 粉体の結合, 油脂の乳化促進などにも 利用されようとしている。

\section{参考文献}

1) H. Nagaoka : Electric Explosions, Sci. Papers. Inst. Phys. Chem. Res., Vol. 8 No. 150(1928) 269.

2) Rupert Le Grand : Underwater "Lightning" Sparks New Metal Forming Process, Amer. Machinist, Vol. 103 No. 22 (1959) 123.

3) J. Frederick Parr : Hydrospark Forming Shapes Space-age Metals, Tool Engr., Vol. 44 No. 3 (1960) 81.

4) H. J. Wagner, J. G. DunLeavy : Hydrospark Forming...Evolution of the Process, Tool Engr., Vol. 44 No. 3 (1960) 83.

5) 藤村勉：放電成形に打ける電流波形の影響につい $\tau$ (第 1 報)，精機学会講演会前刷集 $(1964$, Apr.) 149.

6) A.S.Zingerman : Pressure at the Schock Wave Front as a Function of the Steepness of the Impulse Energy Front during Electrical Discharge in a Fluid, Soviet Phys. Tech. Phys., Vol. 1 (1958) 2454.

7) J.L.Duncan, W. Johnson : The Free Forming of Sheet Aluminium using an Electric Spark Discharge Method, The 1st. Mech. Tool Design \& Res. Confr. 前刷, (1962, Sept.).

8) 井上潔 : 放電圧力加工の諸問題 (4), 機械と工具, 6 巻 4 号 $(1962) 15$.

9) W.F. Cortis : Electrical Discharge Metal Forming, ASME papers 62-MD-23 (1962) 1.

10) Shin-ichi Hyodo-et al. : Adiabatic Expansion of Vapor Bubbles Produced by Underliquid Sparks, 応用物理, 30 巻 12 号 (1961) 871 .

11) 井上友一ほ禾：液中放電成形，精密機械，29巻 10 号 (1963) 803.

12）神野有男ほか：液中放電成形について，川崎航空 機評論， 14 号 (1964) 9.

13）奥島啓武ほか：液中放電成形に関する基礎的研究 (第 1 報)，精密機械，29巻 8 号 (1963) 599.

14) 元不幹雄ほ加：水中衝慗大電流放電の圧力効果, 第14回望性加工連合譵演会前刷集 (1963) 143.

15）奥島啓式ほ加：液中放電成形纪関する基礎的研 究，日本機械学会・精機学会前刷集，No.123 (1964) 143.

16）紹介：海外技術速報，No.33-6.

17) R.L. Kegg : A Study of Energy Requirements 
for Electrical Discharge Metal Forming, Trans. ASME., J. Engg. Indust. , Vol. 86 Ser. B No. 2 (1964) 127.

18）熊沢猛彦ほか：放電成形法の基礎実験, 塑性と加 工, 4 巻26号 (1963) 137.

19）佐野博也ほか：液中放電による金属成型効果につ いて (1), 電気四学会連合大会講演前刷 (1962) 63.

20) 大矢根守哉ほか: 水中放電成形の基礎研究, 日本 機械学会論文集（第 3 部)，29 巻 205 号 (1963) 1491.

21) Th. von Kármán : The Propagation of Plastic Deformation in Solids, J. Appl. Phys., Vol. 21 No. 8 (1950) 987.
22）河田幸三ほか：高速引張りでの伸びについて，応 用物理, 32巻10号 (1963) 742 .

23）作井誠太ほか：金属材料の高速衝撃引張試験，応 用物理, 32巻 10 号 (1963) 731 .

24) W. W. Wood : Combined Effects of High Velocity and Temperature on Sheet Metal Formability, Proc. Inst. Prod. Engg. Res. Confr., (1963) 311.

25) G. E. Hudson : A Theory of the Dynamic Plastic Deformation of a Thin Diaphragm, J. Appl. Phys., Vol. 22 No. 1 (1951) 1.

26）清田堅吉 : 爆発成形における塑性変形の基礎 概 念, 塑性と加工, 3 巻22号 (1962) 767. 